\title{
Optical and physical properties of aerosols in the boundary layer and free troposphere over the Amazon Basin during the biomass burning season
}

\author{
D. Chand ${ }^{1, *}$, P. Guyon ${ }^{1}$, P. Artaxo ${ }^{2}$, O. Schmid ${ }^{1, * *}$, G. P. Frank ${ }^{1}$, L. V. Rizzo ${ }^{2}$, O. L. Mayol-Bracero ${ }^{3}$, L. V. Gatti ${ }^{4}$, and \\ M. O. Andreae ${ }^{1}$ \\ ${ }^{1}$ Max Planck Institute for Chemistry, Mainz, Germany \\ ${ }^{2}$ Institute of Physics, University of São Paulo, São Paulo, Brazil \\ ${ }^{3}$ University of Puerto Rico, San Juan, PR, USA \\ ${ }^{4}$ Institute of Nuclear Energy Research, São Paulo, Brazil \\ * now at: University of Washington-Bothell, Bothell, USA \\ ** now at: GSF-Research Center for Environment and Health, Neuherberg/Munich, Germany
}

Received: 7 March 2005 - Published in Atmos. Chem. Phys. Discuss.: 4 July 2005

Revised: 9 May 2006 - Accepted: 2 June 2006 - Published: 14 July 2006

\begin{abstract}
As part of the Large Scale Biosphere-Atmosphere Experiment in Amazonia - Smoke, Aerosols, Clouds, Rainfall and Climate (LBA-SMOCC) campaign, detailed surface and airborne aerosol measurements were performed over the Amazon Basin during the dry to wet season from 16 September to 14 November 2002. Optical and physical properties of aerosols at the surface, and in the boundary layer (BL) and free troposphere (FT) during the dry season are discussed in this article. Carbon monoxide (CO) is used as a tracer for biomass burning emissions. At the surface, good correlation among the light scattering coefficient $\left(\sigma_{s}\right.$ at $545 \mathrm{~nm}$ ), PM2.5, and $\mathrm{CO}$ indicates that biomass burning is the main source of aerosols. Accumulation of haze during some of the large-scale biomass burning events led to high PM2.5 $\left(225 \mu \mathrm{g} \mathrm{m}^{-3}\right), \sigma_{s}\left(1435 \mathrm{Mm}^{-1}\right)$, aerosol optical depth at $500 \mathrm{~nm}(3.0)$, and CO (3000 ppb). A few rainy episodes reduced the PM2.5, number concentration $(\mathrm{CN})$ and $\mathrm{CO}$ concentration by two orders of magnitude. The correlation analysis between $\sigma_{s}$ and aerosol optical thickness shows that most of the optically active aerosols are confined to a layer with a scale height of $1617 \mathrm{~m}$ during the burning season. This is confirmed by aircraft profiles. The average mass scattering and absorption efficiencies $(545 \mathrm{~nm})$ for small particles (diameter $\mathrm{D}_{p}<1.5 \mu \mathrm{m}$ ) at surface level are found to be 5.0 and $0.33 \mathrm{~m}^{2} \mathrm{~g}^{-1}$, respectively, when relating the aerosol optical properties to PM2.5 aerosols. The observed mean single scattering albedo $\left(\omega_{o}\right.$ at $\left.545 \mathrm{~nm}\right)$ for submicron aerosols at the surface is $0.92 \pm 0.02$. The light scattering by particles
\end{abstract}

Correspondence to: D. Chand

(duli@mpch-mainz.mpg.de)
$\left(\Delta \sigma_{s} / \Delta \mathrm{CN}\right)$ increase 2-10 times from the surface to the FT, most probably due to the combined affects of coagulation and condensation.

\section{Introduction}

The gas and particle emissions from tropical biomass burning influence the physical, chemical and optical properties of the atmosphere (Andreae et al., 1988, 2002; Crutzen and Andreae, 1990; Andreae and Crutzen, 1997; Hobbs et al., 1997, 2003; Artaxo et al., 1998, 2001, 2002; Andreae and Merlet, 2001, Ramanathan et al., 2001). Smoke aerosols contain a significant amount of partially oxidized organic material and black carbon or soot, which may have significant climatic implications (IPCC, 2001). Aerosol particles interact directly with the incoming solar radiation by the scattering and absorption of light (Charlson et al., 1992; Rosenfeld, 2000; Andreae et al., 2004) and because they act as cloud condensation nuclei $(\mathrm{CCN})$, thereby affecting indirectly the Earth's radiation budget. The importance of aerosol particles for climate forcing is recognized, but the magnitude of their contribution is highly uncertain (IPCC, 2001). It is thought that particles, through their combined direct and indirect effects, may currently have an influence of potentially similar magnitude, but opposite sign, as greenhouse gas forcing (IPCC, 2001). Aerosol radiative forcing may range from net heating to net cooling, depending on the aerosol properties as well as on the albedo of the boundary layer and free troposphere aerosols. Particles, with their short atmospheric lifetimes, have significant vertical, horizontal and temporal

Published by Copernicus GmbH on behalf of the European Geosciences Union. 
concentration gradients. These spatial gradients correspond to significant local/regional as well as global aerosol forcing effects. For example, smoke layers over the Amazon basin can have significant regional effects by reduction of regional photosynthetically active radiation up to $45 \%$ (Eck et al., 1998). Because of their light absorbing properties, the presence of aerosol particles can result in the radiative forcing at the surface being much larger than at the top of the atmosphere (Satheesh and Ramanathan, 2000; Ramanathan et al., 2001; Procópio et al., 2003, 2004).

Biomass burning, particularly in the tropics, is a major source of atmospheric trace gases and particles (Andreae and Merlet, 2001). Being the world's largest rain forest area containing approximately one quarter of all tropical rainforests, the Amazon Basin is subject to one of the highest rates of deforestation in the world (Gash et al., 1996). About $80 \%$ of the global burning activity is taking place in the tropics and one third of it occurs in South America alone. Under suitable meteorological conditions, the local chemical, physical, and optical characteristics of aerosols can be much different from the global or regional averages and these characteristics, in turn, are strongly influenced by local and regional sources and perturbations, e.g., forest emissions, fires, dust, sea salt, etc., leading to further spatial and temporal inhomogeneity.

Aerosol optical properties over the Amazon Basin have been studied in the previous LBA and SCAR-B experiments (e.g., Eck et al., 1998, 2003; Kotchenruther and Hobbs, 1998; Martins et al., 1998; Reid et al., 1998; Reid and Hobbs, 1998; Ross et al., 1998, Guyon et al., 2003a, 2004; Reid et al., $2005 \mathrm{a}, \mathrm{b})$. In these studies, the variability in aerosol optical properties has been analyzed based on either surface or airborne measurements. However, so far, it is not understood how aerosol properties at the surface relate to those aloft in the boundary layer (BL) ${ }^{1}$ and free troposphere. In addition to the limited surface observations, only a few series of insitu vertical profile measurements of aerosol optical properties (e.g., light absorption, light scattering, hemispheric backscattering) have been made over the Amazon Basin (e.g., Kotchenruther and Hobbs, 1998; Reid et al., 1998, 2005a, b; Ross et al., 1998; Guyon et al., 2003a, c). To our knowledge, almost no simultaneous observations of optical properties of aerosols and trace gases at the surface and aloft are available over the Amazon Basin in the biomass burning season.

This paper describes the vertical distribution of aerosol optical and physical properties over the Amazon Basin during the 2002 biomass burning season. The observations of light scattering $\left(\sigma_{s}\right)$, light absorption $\left(\sigma_{a}\right)$, aerosol optical thickness (AOT), aerosol number density $(\mathrm{CN})$, aerosol mass concentration (PM2.5), and carbon monoxide (CO) are being used to address the following scientific questions: (1) How does $\sigma_{s}$ vary at the surface, in the boundary layer and free tro-

\footnotetext{
${ }^{1}$ Boundary layer (BL) is the lowest layer of the atmosphere near ground affected by diurnal heat, moisture or momentum transfer to or from the surface.
}

posphere? (2) How does $\sigma_{s}$ vary vertically at different sites over the Amazon Basin? (3) How do Ångström exponent observations from the airborne measurements compare with vertically integrated measurements using a sunphotometer?

\section{Instrumentation and methods}

\subsection{Observational sites}

The measurements were made over the Amazon Basin during the Large Scale Biosphere-Atmosphere Experiment in Amazonia - Smoke, Aerosols, Clouds, Rainfall and Climate (LBA-SMOCC) from 16 September to 14 November in 2002. Detailed surface observations of aerosols and trace gases were made in the state of Rondônia, Brazil at a pasture site "Fazenda Nossa Senhora Aparecida" $\left(10.76^{\circ} \mathrm{S}\right.$, $62.32^{\circ} \mathrm{W}, 315 \mathrm{~m}$ above mean sea level (a.m.s.l.)), hereafter FNS. This experimental site is located about $57 \mathrm{~km}$ north-west of the town of Ji-Paraná $\left(10.88^{\circ} \mathrm{S}, 61.85^{\circ} \mathrm{W}\right.$, $235 \mathrm{~m}$ a.m.s.l.). A few small hills (300-400 m a.m.s.l.) are located about 1-4 km from FNS. One hill, known as "Abracos Hill", is one of the AERONET (Aerosol Robotic Network) sites and provides column integrated aerosol optical thickness (AOT) measurements using sun-photometry observations (Holben et al., 1998). Further details on the FNS site can be found elsewhere (Kirkman et al., 2002; Trebs et al., 2004). Airborne measurements in the BL and free troposphere (FT, up to $4200 \mathrm{~m}$ ) over the Amazon Basin were taken as far as $800 \mathrm{~km}$ from FNS. Some selected flight tracks along with the geographical location of the surface measurement site FNS are shown in Fig. 1. More details on this campaign are given in Andreae et al. (2004).

\subsection{Measurements and methods}

The surface observations at FNS over the Amazon basin were conducted from the middle of the smoky dry season (16 September) to the onset of the wet season (14 November), when pollution levels approached background conditions. In this study, we make use of ground based observations from 16 September to 8 October representing the biomass burning season during the SMOCC campaign.

Aerosol mass (PM2.5) and $\sigma_{s}$ measurements at FNS were made using dried air $(R H<40 \%)$ sampled from an inlet installed at about $10 \mathrm{~m}$ above the ground level. The hygroscopic growth in scattering coefficient at $R H 30-50 \%$ is low $(<10 \%)$ for the observed submicron aerosols $(<1.5 \mu \mathrm{m})$. The details of the measured parameters are given in Table 1. The $\sigma_{s}$ and $\sigma_{a}$ of dried aerosols at FNS were measured for the submicron size particles. An impactor with a cut off diameter at $1.5 \mu \mathrm{m}$ was used to remove the bigger particles (Table 2). Before selection through the impactor, the aerosols were dried by passing them through a Permapure Nafion drier. The drier unit and impactor (with and without impaction plate) were characterized for aerosol losses using 
Table 1. Summary of the optical and physical properties of aerosols along with CO concentration at surface (S), boundary layer (BL) and free troposphere (FT) during the biomass burning season. The availability of measurements at S, BL and FT are shown by right $(\sqrt{ })$ sign and the " $\mathrm{x}$ " shows the parameters with no observations.

\begin{tabular}{|c|c|c|c|c|}
\hline \multirow[t]{2}{*}{ Parameter with units } & \multirow[t]{2}{*}{ Symbols } & \multicolumn{3}{|c|}{ Measurements } \\
\hline & & $\mathrm{S}$ & $\mathrm{BL}$ & FT \\
\hline Light scattering coefficient at $545,550 \mathrm{~nm}\left(\mathrm{Mm}^{-1}\right)$ & $\sigma_{s}$ & $\sqrt{ }$ & $\sqrt{ }$ & $\sqrt{ }$ \\
\hline Light absorption coefficient at $532 \mathrm{~nm}\left(\mathrm{Mm}^{-1}\right)$ & $\sigma_{a}$ & $\sqrt{ }$ & $\mathrm{x}$ & $\mathrm{x}$ \\
\hline Condensation nuclei $\left(\mathrm{cm}^{-3}\right)$ & $\mathrm{CN}$ & $\sqrt{ }$ & $\sqrt{ }$ & $\sqrt{ }$ \\
\hline Aerosol mass $\left(\mathrm{g} \mathrm{cm}^{-3}\right)$ & PM2.5 & $\sqrt{ }$ & $\mathrm{x}$ & $\mathrm{x}$ \\
\hline Aerosols optical thickness at $440,670 \mathrm{~nm}$ & AOT & \multicolumn{3}{|c|}{ Column integrated } \\
\hline Carbon monoxide $(\mathrm{ppb})$ & $\mathrm{CO}$ & $\sqrt{ }$ & $\sqrt{ }$ & $\sqrt{ }$ \\
\hline Single scattering albedo (using $\sigma_{s}$ and $\sigma_{a}$ ) at $545 \mathrm{~nm}^{*}$ & $\omega_{o}$ & $\sqrt{ }$ & $\mathrm{x}$ & $\mathrm{x}$ \\
\hline Excess ratio $\left(\Delta \sigma_{S} / \Delta \mathrm{CN}\right)$ & $\Delta \sigma_{s} / \Delta \mathrm{CN}$ & $\sqrt{ }$ & $\sqrt{ }$ & $\sqrt{ }$ \\
\hline Excess ratio $\left(\Delta \sigma_{s} / \Delta \mathrm{CO}\right)$ & $\Delta \sigma_{s} / \Delta \mathrm{CO}$ & $\sqrt{ }$ & $\sqrt{ }$ & $\sqrt{ }$ \\
\hline Excess ratio $\left(\Delta \sigma_{s} / \Delta \mathrm{PM} 2.5\right)$ or Mass scattering efficiency $\left(\mathrm{m}^{2} \mathrm{~g}^{-1}\right)^{*}$ & $\Delta \sigma_{s} / \Delta \mathrm{PM} 2.5$ & $\sqrt{ }$ & $\mathrm{x}$ & $\mathrm{x}$ \\
\hline Excess ratio $\left(\Delta \sigma_{a} / \Delta \mathrm{PM} 2.5\right)$ or Mass absorption efficiency $\left(\mathrm{m}^{2} \mathrm{~g}^{-1}\right)^{*}$ & $\Delta \sigma_{a} / \Delta \mathrm{PM} 2.5$ & $\sqrt{ }$ & $\mathrm{x}$ & $\mathrm{x}$ \\
\hline
\end{tabular}

* To match $\sigma_{s}$ wavelength, the $\sigma_{a}$ observation at $532 \mathrm{~nm}$ are converted to $545 \mathrm{~nm}$. The calculated $\omega_{o}, \sigma_{a}$ and $\sigma_{s}$ are presented at $545 \mathrm{~nm}$

Table 2. The size cut-point (aerodynamic diameter) of the aerosols property is given by $\mathrm{D}_{\mathrm{p}-\text { cut }}$.

\begin{tabular}{llll}
\hline Aerosol parameter & Dry/Ambient & Symbol & $\mathrm{D}_{\mathrm{p}-\text { cut }}$ \\
\hline Light scattering coefficient $(545 \mathrm{~nm}$ ) at ground (FNS) & (D) & $\sigma_{s}$ & $1.5 \mu \mathrm{m}$ \\
Light scattering coefficient $(550 \mathrm{~nm}$ ) in BL (aircraft) & (A) & $\sigma_{s}$ & - \\
Light absorption coefficient at $532 \mathrm{~nm}^{*}$ & (D) & $\sigma_{a}$ & $1.5 \mu \mathrm{m}$ \\
Condensation nuclei $\left(\mathrm{cm}^{-3}\right)$ & (A) & $\mathrm{CN}$ & - \\
Aerosols optical thickness at 440,670 nm & (A) & AOT & - \\
Particulate mass & (A) & PM2.5 & $2.5 \mu \mathrm{m}$ \\
Single scattering albedo for FNS observations & (D) & $\omega_{o}$ & $1.5 \mu \mathrm{m}$ \\
Mass absorption efficiency $\left(\mathrm{m}^{2} \mathrm{~g}^{-1}\right)$ & (D) & $\alpha_{a}$ & $1.5 \mu \mathrm{m}^{\dagger}$ \\
Mass scattering efficiency $\left(\mathrm{m}^{2} \mathrm{~g}^{-1}\right)$ & (D) & $\alpha_{s}$ & $1.5 \mu \mathrm{m}^{\dagger}$ \\
\hline
\end{tabular}

* To match the $\sigma_{s}$ wavelength, the $\sigma_{a}$ observation at $532 \mathrm{~nm}$ are converted to $545 \mathrm{~nm}$

$\dagger$ based on correlations of $\sigma_{s}$ and $\sigma_{a}$ with PM2.5; (A) Ambient aerosol; (D) Dry aerosol

ammonium sulfate particles in the lab at the same flows as used in the field campaign. We used a series of lab experiments to characterize the losses in the impactor and Nafion drier. First, dried particles of the desired diameter were selected using the SMPS, and then these size-selected aerosols were counted before and after passing through the Nafion tube. Similar experiments were conducted using the combined (Nafion+impactor) units. To avoid particle losses in the lines, smooth bends were used and the flow was optimized. Most of the losses are confined to very small sizes (diameter $<60 \mathrm{~nm}$ ) that have very little effect on the measured $\sigma_{s}$ and $\sigma_{a}$. Using Mie theory and the measured on-site particle size distributions we found a $2-4 \%$ reduction in $\sigma_{s}$ and $\sigma_{a}$ during the burning season. All the $\sigma_{s}$ and $\sigma_{a}$ data sets at FNS were corrected for these losses. Non-lambertian correction on $\sigma_{s}$ is applied for dried aerosols as per Anderson and Ogren (1998). The radiance research (RR) nephelome- ter, photoacoustic spectrometer (PAS) and particle soot absorption photometer (PSAP) were operating downstream of the impactor-drier units, and the losses observed by these instruments were of the same order.

Airborne measurements of aerosols and trace gases were made from 25 September to 19 October (about 31 flights). For this study, we make use of the airborne measurements of $\sigma_{s}$, aerosol number density $(\mathrm{CN})$, limited available size distribution (diameter, $\mathrm{D}_{p}=42-346 \mathrm{~nm}$ ) and carbon monoxide (CO) from selected flights (numbers 4, 6, 7, 8 and 24), which include measurements conducted directly above FNS and its surroundings. A Scanning Mobility Particle Sizer (SMPS, TSI Model 3080) was used to measure the diameter of the submicron aerosols during the airborne observations. The flight tracks of these observations along with dates are shown in Fig. 1 with complementary data in Table 3. Most of the flights were conducted during afternoon 


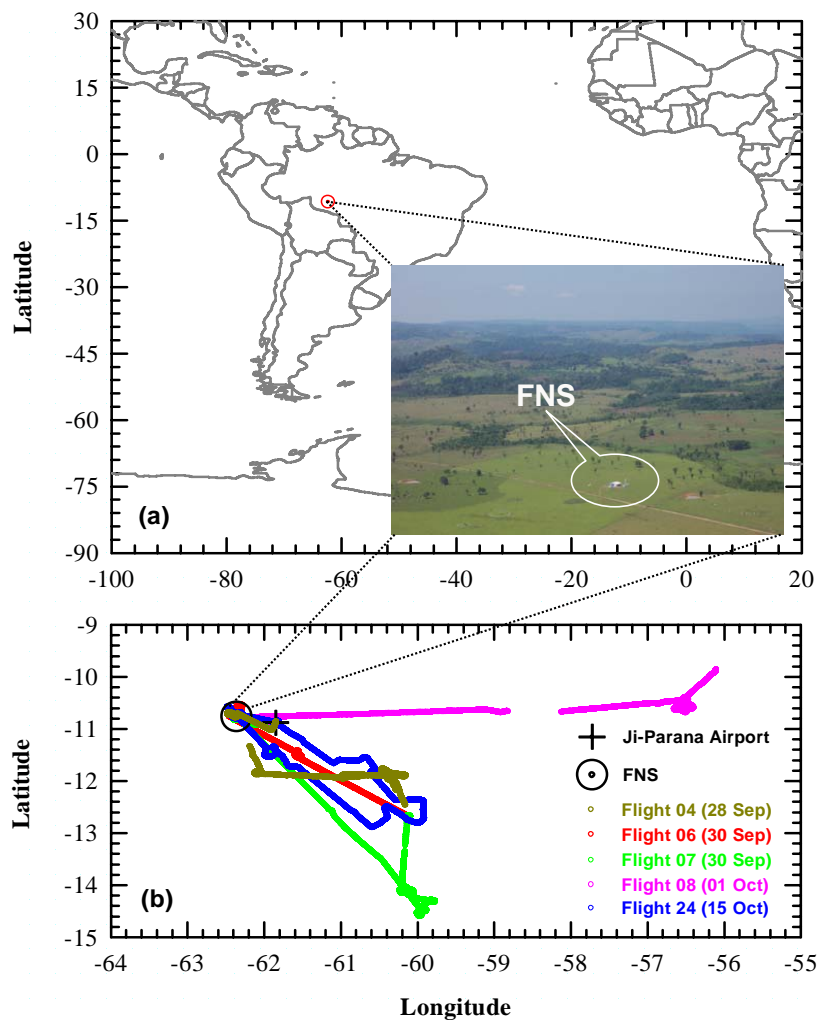

Fig. 1. (a) Overview map showing the geographical location of the surface site FNS. The picture is an aerial view of the site. (b) Flight tracks for flights $4,6,7,8$, and 24 . The positions of FNS and the nearby Ji-Paraná airport are shown by the circle and cross symbols, respectively.

hours (14:00 LT=18:00 UT) when the BL was well developed. Flights 6 and 7 were conducted on the same day during morning and afternoon hours, respectively. The measurements were taken up to a height of $4200 \mathrm{~m}$. The time schedule of the studied parameters, their symbols, and further details on the surface and airborne observations are given in Tables 1-4. Some other details on the aircraft measurements can be found in Guyon et al. (2005).

The time resolution of the $\sigma_{s}$ and $\sigma_{a}$ measurements at FNS was one minute; they were averaged over longer intervals ( $30 \mathrm{~min})$ to match the averaging time of the aerosol mass (PM2.5) measurement. A real-time aerosol mass monitor, the Tapered Element Oscillating Microbalance (TEOM, series 1400a, Rupprecht \& Patashnick Inc.) was used to measure PM2.5 aerosol mass concentration with a time resolution of $30 \mathrm{~min}$. The TEOM inlet was heated to $50^{\circ} \mathrm{C}$ for drying the aerosols. The aerosol number density was measured using a TSI condensation particle/nuclei $(\mathrm{CN})$ counter (model 3022A) with a minimum detection size of $8 \mathrm{~nm}$. At the ground site $\mathrm{CO}$ was measured with the Thermo Environmental Instrument Inc. analyzer (Model 48C Gas Filter Correlation) with a minimum detection limit of $40 \mathrm{ppb}$. Because of the high ambient humidity, a cooler was used to remove water from the sample stream prior to the $\mathrm{CO}$ analyzer. The $\mathrm{CO}$ measurements on the aircraft were made using an AeroLaser (AL5002) instrument operating at $1 \mathrm{~Hz}$. Prior to sampling, the air was dried using a Nafion drier in the CO instrument. The $\mathrm{CO}, \sigma_{s}$ and $\mathrm{CN}$ were measured both at the ground site and on the aircraft. The airborne observations are compared with measurement at FNS during fly-by over FNS at height of $150-600 \mathrm{~m}$. These data (1-3 min every flight) were used to compare the observations at surface and aloft. The $\mathrm{CN}$ are found higher in the airborne observations by $5-10 \%$ compared to FNS. Also, the ratios of the $\sigma_{s}$ and $\mathrm{CO}$ from airborne observation were higher compared to FNS by $10-25 \%$ during these fly-by flights.

Under suitable wind conditions, the transport of pollutants from fossil fuel combustion (like cars and trucks from a nearby road) contaminated the data for short periods. The time periods with winds coming from the direction of the road, having high $\mathrm{CO}$, nitric oxides $\left(\mathrm{NO}_{\mathrm{x}}\right)$ and low single scattering albedo $\left(\omega_{o}\right)$ were assumed to be affected by cars and trucks; these data $(<5 \%$ of the total data set) were removed and not considered in this study. Aerosol properties, for instance, $\sigma_{s}, \sigma_{a}$, AOT and PM2.5 averaged for $30 \mathrm{~min}$ intervals were used to derive the intensive optical properties like $\omega_{o}$, mass scattering efficiency $\left(\alpha_{s}\right)$, mass absorption efficiency $\left(\alpha_{a}\right)$ and Ångström exponent (å). The dried size distribution of aerosols $\left(\mathrm{D}_{p}=10-414 \mathrm{~nm}\right)$ in the BL and FT was measured using a TSI scanning mobility particle sizer (SMPS model 3080). In some of the flights the size scans were made to smaller sizes only $\left(D_{p}=346 \mathrm{~nm}\right)$. Since most of the smallest aerosols do not contribute significantly to the in light scattering, the always available size range from 42 up to $346 \mathrm{~nm}$ are used for calculating the scattering efficiency $\left(\Delta \sigma_{s} / \Delta \mathrm{CN}\right)$. The size scans were made over 2 min each. The next section describes the details of the methods and measurements used to derive the optical properties.

\subsection{Aerosol optical properties}

\subsubsection{Aerosol light scattering}

The light scattering properties of the dried aerosols were measured using two Radiance Research (RR, model M903) and one TSI (TSI, model 3563) nephelometers. The RR nephelometer measures $\sigma_{s}$ at a single wavelength $(545 \mathrm{~nm})$ whereas the TSI nephelometer measures $\sigma_{s}$ at three wavelengths $(450,550,700 \mathrm{~nm})$. The RR nephelometers were employed at the ground site (FNS) for simultaneous measurements of light scattering of dried and ambient aerosols. The TSI nephelometer was used for airborne observations. The calibrations of the nephelometers and the basic measurement strategy adopted herein have been described by Anderson and Ogren (1998). All the nephelometers used at the surface as well as in the airborne observations were calibrated during the field campaign using particle-free air and $\mathrm{CO}_{2}$ as a 
Table 3. Correlations of light scattering coefficient $\left(\sigma_{s}\right)$ with $\mathrm{CO}$ and $\mathrm{CN}$ from the airborne (boundary layer-BL and free troposphere-FT $550 \mathrm{~nm})$ and surface observations $(545 \mathrm{~nm})$ at FNS. The flights, shown by the respective numbers were conducted on the dates given in brackets in column 1 . The correlation coefficients $\left(\mathrm{r}^{2}\right)$ of the slopes $\Delta \sigma_{s} / \Delta \mathrm{CN}$ and $\Delta \sigma_{s} / \Delta \mathrm{CO}$ are given in parenthesis.

\begin{tabular}{|c|c|c|c|c|c|}
\hline $\begin{array}{l}0 \\
0 \\
.0 \\
0 \\
0 \\
0 \\
0 \\
0 \\
0 \\
0\end{array}$ & Flight No [Date] & $\begin{array}{l}\left(\Delta \sigma_{s} / \Delta \mathrm{CN}\right)_{B L} \\
\left(\mathrm{Mm}^{-1} \mathrm{~cm}^{-3}\right)\end{array}$ & $\begin{array}{l}\left(\Delta \sigma_{s} / \Delta \mathrm{CN}\right)_{F T} \\
\left(\mathrm{Mm}^{-1} \mathrm{~cm}^{-3}\right)\end{array}$ & $\begin{array}{l}\left(\Delta \sigma_{S} / \Delta \mathrm{CO}\right)_{B L} \\
\left(\mathrm{Mm}^{-1} \mathrm{ppb}^{-1}\right)\end{array}$ & $\begin{array}{l}\left(\Delta \sigma_{S} / \Delta \mathrm{CO}\right)_{F T} \\
\left(\mathrm{Mm}^{-1} \mathrm{ppb}^{-1}\right)\end{array}$ \\
\hline \multirow{5}{*}{$\begin{array}{l}\stackrel{\Xi}{\Xi} \\
\stackrel{0}{Z} \\
:\end{array}$} & 04 [28 September] & $0.011(0.14)$ & $0.12(0.79)$ & $0.36(0.55)$ & $1.02(0.80)$ \\
\hline & 06 [30 September] & $0.015(0.64)$ & $0.037(0.76)$ & $0.38(0.67)$ & - \\
\hline & 07 [30 September] & $0.018(0.76)$ & $0.026(0.50)$ & $0.38(0.67)$ & - \\
\hline & 08 [1 October] & $0.019(0.57)$ & $0.033(0.55)$ & $0.38(0.67)$ & - \\
\hline & 24 [15 October] & $0.019(0.57)$ & $0.076(0.73)$ & $0.40(0.60)$ & $1.50(0.45)$ \\
\hline$\underset{\mathscr{\Xi}}{\stackrel{\mathscr{Z}}{\Xi}}$ & 16 Septmber-8 October & $0.03(0.30)$ & - & $0.43(0.88)$ & - \\
\hline
\end{tabular}

Table 4. Average Ångström exponent calculated from the airborne (nephelometer, $\mathrm{a}_{s}$ ) and integrated (sunphotometer, $\mathrm{a}_{e}$ ) observations. The wavelengths $\lambda_{1}$ and $\lambda_{2}$ used for computing the Ångström exponent from the nephelometer and the sunphotometer are 450-700 nm and 440-670 nm. In addition to the average $\stackrel{a}{e}_{e}$ during the airborne observation days, an average Ångström exponent is also calculated for the entire burning period. SD represents the standard deviation from the number of observations shown by the counts. Each count from airborne observations is $1 \mathrm{~s}$ whereas for the sunphotometer it is about $15 \mathrm{~min}$.

\begin{tabular}{|c|c|c|c|c|c|c|c|}
\hline \multirow[t]{2}{*}{ Observations } & \multirow[t]{2}{*}{ Flight No (Date) } & \multicolumn{3}{|c|}{$\begin{array}{l}\text { Ångström Exponent, } \\
\mathrm{å}_{s}(450-700 \mathrm{~nm}) \\
\text { Airborne nephelometer }\end{array}$} & \multicolumn{3}{|c|}{$\begin{array}{c}\text { Ångström Exponent, } \\
\mathrm{å}_{e}(440-670 \mathrm{~nm}) \\
\text { Sunphotometer }\end{array}$} \\
\hline & & Avg. & SD & Counts & Avg. & SD & Counts \\
\hline \multirow{8}{*}{ Individual days } & - (21 September) & - & - & - & 1.74 & 0.05 & 8 \\
\hline & - (25 September) & - & - & - & 2.01 & 0.04 & 11 \\
\hline & $-(5$ October $)$ & - & - & - & 1.85 & 0.02 & 10 \\
\hline & 04 (28 September) & 1.90 & 0.33 & 10106 & 1. 70 & 0.05 & 11 \\
\hline & 06 (30 September) & 1.98 & 0.41 & 8103 & 1.57 & 0.04 & 7 \\
\hline & 07 (30 September) & 2.06 & 0.35 & 11149 & 1.57 & 0.04 & 7 \\
\hline & 08 (1 October) & 2.11 & 0.31 & 5269 & 1.40 & 0.13 & 13 \\
\hline & 24 (15 October) & 1.98 & 0.19 & 13166 & 1.53 & 0.06 & 3 \\
\hline Burning events & (16-27 September) & - & - & - & 1.8 & 0.2 & 122 \\
\hline
\end{tabular}

span gas. All the nephelometers were inter-compared by running them parallel to each other after the end of the airborne campaign. After including calibration factors, truncation correction and non-lambertian correction, good agreement was found (within 5\%) in all the nephelometers at surface. Measurements of the total scattering coefficient in the RR and TSI nephelometers cover the angles $9-170^{\circ}$ and $7-170^{\circ}$, respectively. The RR nephelometer data at FNS are corrected for the truncated angles using Mie calculations. The truncated angles $\left(0-9^{\circ}, 170-180^{\circ}\right)$ contribute about $4 \%$ of the total light scattering by the dried fine aerosols $\left(\mathrm{D}_{p}<1.5 \mu \mathrm{m}\right)$ in the biomass burning season. The truncation angles in the TSI nephelometer are slightly smaller $\left(0-7^{\circ}, 170-180^{\circ}\right)$ compared to the RR nephelometer. Based on the Mie calculations performed by us and Guyon et al. (2003c), the contribution by the truncated angles may be $4-16 \%$ of the total light scattering depending on the particle size distribution. However, due to unavailability of complete size distribution, $\sigma_{s}$ is not corrected for truncation errors for the airborne observations using the TSI nephelometer. All the data from both the nephelometers (RR and TSI) presented in this article are converted to a standard temperature $\left(25^{\circ} \mathrm{C}\right)$ and pressure $(1000 \mathrm{hPa})$ using the method described by Anderson and Ogren (1998). The estimated combined accuracy of $\sigma_{s}$ is $<10 \%$. 
The spectral dependence of $\sigma_{s}$ can be derived from the multi-wavelength (TSI nephelometer) measurements. This dependence is an intensive parameter in the sense that it depends on the aerosol size distribution and refractive index but, contrary to $\sigma_{s}$ (at a wavelength $\lambda$ ) not on the aerosol concentration. It is generally assumed that the wavelength dependence of the scattering coefficient from the nephelometer can be described in the visible spectrum by an empirical equation as a power law of $\lambda$ (Ångström, 1929):

$\sigma_{s}(\lambda)=\beta_{s} \lambda^{-\stackrel{\circ}{a}_{s}}$

where $\sigma_{s}(\lambda)$ is the scattering coefficient at wavelength $\lambda, \beta_{s}$ is a constant, and $\AA_{s}$ is the non-dimensional Ångström exponent. In order to cover the widest possible spectral range, we compute $\stackrel{a}{s}_{s}$ from the nephelometer measurements at $450 \mathrm{~nm}$ and $700 \mathrm{~nm}$ to obtain $\stackrel{\circ}{s}_{s}$ i.e.,

$\stackrel{\circ}{s}_{s}=-\frac{\log \left[\sigma_{s}\left(\lambda_{1}\right) / \sigma_{s}\left(\lambda_{2}\right)\right]}{\log \left(\lambda_{1} / \lambda_{2}\right)}$

The variability in $\stackrel{\circ}{s}_{s}$ can be used to provide an insight on the types of aerosol from the nephelometer observations, since Mie theory shows that $\AA_{s}$ increases with decreasing aerosol particles size. For instance, $\stackrel{\mathrm{a}}{s}_{s}$ values for fine anthropogenic aerosol encountered in polluted areas are typically larger than 1 , whereas $\stackrel{\circ}{s}_{s}$ is low $(\sim 0.3)$ in regions dominated by coarse mode desert dust (Horvath and Trier, 1993; Eck et al., 1999). The mass scattering efficiency $\alpha_{s}$ is derived by normalizing the scattering coefficient $\sigma_{s}$ with PM2.5 obtained from the TEOM.

\subsubsection{Aerosol light absorption}

The $\sigma_{a}$ of aerosol particles was measured by a Particle Soot Absorption Photometer (PSAP) calibrated using a Photoacoustic spectrometer (PAS) as a reference. The PSAP measures $\sigma_{a}$ based on the attenuation of light $(565 \mathrm{~nm})$ through a particle-loaded filter. Although Bond et al. (1999) have provided a calibration for the PSAP using laboratory-generated model aerosols and an optical extinction cell combined with an integrating nephelometer as reference, its validity for atmospheric aerosol is questionable, since the calibration is likely to depend on parameters such as aerosol size, single scattering albedo and $R H$ (Weingartner et al., 2003, Arnott et al., 2003). In order to correct for potentially resulting systematic errors, we calibrated the PSAP in the field with a PAS (Arnott et al., 1999), which measures $\sigma_{a}(532 \mathrm{~nm})$ by converting the absorbed energy into an acoustic wave (Terhune and Anderson, 1977). In contrast to filter-based methods like the PSAP, the PAS measurement is performed on particles in their suspended state, i.e., sampling artefacts due to filter-particle interactions (Arnott et al., 2005) are avoided, and the PAS can be calibrated in the field using $\mathrm{NO}_{2}$ as calibration gas (Arnott et al., 2000; Schmid et al., 2005). Laboratory studies with soot and biomass burning aerosols have shown good agreement between the PAS (accuracy 5\%) and an optical extinction cell (Schnaiter et al., 2005). To avoid potential complications in both PAS and PSAP due to elevated $R H$ (Arnott et al., 2003), both the instruments were operated with dried aerosol $(R H<50 \%)$. The known PAS cross-sensitivity to $\mathrm{NO}_{2}$ (Arnott et al. 2000) was corrected based on continuous $\mathrm{NO}_{2}$ measurements with a $\mathrm{NO}_{\mathrm{x}}$ analyzer (Trebs et al., 2006). For the PSAP calibration, the PAS and PSAP were operated in parallel for several days during the campaign as described in detail by Schmid et al. (2005). The calibration revealed that for relative humidity $(R H)$ between $35 \%$ and $50 \%$ (inside the PSAP) the Bond-corrected PSAP overpredicted $\sigma_{a}$ by about $18 \%$. On the other hand, for some sampling periods with low $R H$ (between $20 \%$ and $35 \%$ ), as encountered during nighttime due to a higher drying efficiency of the nafion unit, the $\sigma_{a}$ ratio of the PSAP (with Bond correction) and PAS decreased for unknown reasons from 1.18 to 0.65 possibly. Hence, the Bond correction, that is based on laboratory-generated nigrosin and ammonium sulfate aerosol, shows satisfactory agreement with the PSAP field calibrations except for some nighttime periods. After correcting for these systematic errors we assume the accuracy of $\sigma_{a}$ measurements to be $<15 \%$.

Analogous to $\alpha_{s}$, the mass absorption efficiency $\left(\alpha_{a}\right)$ is computed by normalizing $\sigma_{a}$ with the aerosol mass concentration obtained from PM2.5. Furthermore, the single scattering albedo $\left(\omega_{o}\right)$ is defined as

$\omega_{o}=\frac{\sigma_{s}}{\sigma_{s}+\sigma_{a}}$

Since the light scattering and absorption coefficients (i.e. $\sigma_{s}$, $\sigma_{a}$ ) were measured at $545 \mathrm{~nm}$ and $532 \mathrm{~nm}$, respectively, we converted $\sigma_{a}$ from 532 to $545 \mathrm{~nm}$ using a power law relationship as given in Eq. (1), where the absorption Ångström exponent was determined from the 450 and $615 \mathrm{~nm}$ channel of a multiple wavelengths Aethalometer (AE30, Magee Scientific) (Arnott et al., 2005), which was operated in parallel with a slightly larger inlet cutoff diameter than the $\operatorname{PSAP}(2.5 \mu \mathrm{m}$ versus $1.5 \mu \mathrm{m})$ and under ambient conditions. Henceforth, $\sigma_{s}, \sigma_{a}$ and $\omega_{o}$ will be presented at $545 \mathrm{~nm}$. For the high pollution events, the absorption Ångström exponent reached values of about 2 , which is close to what Kirchstetter et al. (2004) reported for biomass smoke particles from Africa.

Due to the elevated operating temperature in the TEOM $\left(50^{\circ} \mathrm{C}\right)$, some of the organic matter have evaporated from aerosols. Simultaneous observations of TEOM and filterbased gravimetric mass indicate that the difference in gravimetrical and TEOM measurement of PM2.5 resulted in an underestimation of PM2.5 by $8 \%$. This correction based on gravimetric method is applied in the PM2.5 data. This correction propagates in the $\sigma_{s}$ and $\sigma_{a}$ calculations.

\subsubsection{Aerosol optical thickness}

A sunphotometer (CIMEL, model CE 318-1) described by Holben et al. (1998) was set up on Abracos hill about $4 \mathrm{~km}$ 
from the ground station FNS as a part of the AERONET network. The sunphotometer is used to measure column aerosol optical thickness (AOT) at 7 wavelengths (340, 380, $440,500,670,870$ and $1020 \mathrm{~nm}$ ). The AOT data have been screened for cloud events according to a standardized procedure (Smirnov et al., 2000). The value of the AOT is indicative of the extinction of the solar radiation due to the columnar aerosol content and, similar to $\sigma_{s}$, the wavelength dependence of AOT can be expressed by a power law empirical equation (Ångström, 1929):

$\operatorname{AOT}(\lambda)=\beta_{e} \lambda^{-\stackrel{̊}{a}_{e}}$

where

$\stackrel{\circ}{e}_{e}=-\frac{\log \left[\operatorname{AOT}\left(\lambda_{1}\right) / \operatorname{AOT}\left(\lambda_{2}\right)\right]}{\log \left(\lambda_{1} / \lambda_{2}\right)}$

To calculate the Ångström exponent $\left(\stackrel{\circ}{e}_{e}\right)$, we will be using the AOT at two wavelengths, $440 \mathrm{~nm}$ and $670 \mathrm{~nm}$, which are very close to the $\stackrel{\circ}{s}_{s}$ wavelengths $(450,700 \mathrm{~nm})$ measured by the nephelometer. The Ångström exponents from two independent methods $\left(\stackrel{\circ}{s}_{s}, \stackrel{\mathrm{a}}{e}_{e}\right)$ provide information on the aerosol size distribution averaged over height during the airborne observations as well as over the atmospheric column using the AOT measurements.

\subsubsection{Excess ratios}

Biomass burning emission information is usually represented in two basic forms: emission ratios or emission factors (Andreae and Merlet, 2001). These parameters relate the emission of a particular species of interest to that of a reference species, such as $\mathrm{CO}_{2}$ to $\mathrm{CO}$ (for gases) and $\sigma_{s}$ to $\mathrm{CO}$ (for aerosols-gases). To obtain "excess" concentrations, the ambient background concentrations must be subtracted from the values measured in the sample air. The method for calculation of the excess emission ratio (ER) is discussed in detail in Andreae and Merlet (2001) and in Le Canut et al. (1996), i.e.,

$\mathrm{ER}=\frac{\Delta y}{\Delta x}$

where $\Delta y / \Delta x$ is the average slope of correlation of species " $y$ " with respect to " $x$ " in a biomass burning environment (plume and/or haze mixed in the background air). The advantage of this method is that it is not necessary to estimate the background concentration of the species while computing the ER. Equation (6) is used to calculate the excess ratios of $\sigma_{s}$ to $\mathrm{CO}, \sigma_{s}$ to $\mathrm{CN}, \sigma_{s}$ to PM2.5, and $\sigma_{a}$ to PM2.5 for both the regional haze as well as smoke plumes.

\section{Results and discussions}

\subsection{Measurements at the ground site FNS}

Figure 2 shows the 30-min averaged time series of $\sigma_{s}, \sigma_{a}$, PM2.5 and $\mathrm{CO}$ for the burning season at FNS. A large


Fig. 2. Temporal variation of PM2.5 (diamonds), light absorption coefficient at $545 \mathrm{~nm}\left(\sigma_{a}\right.$, squares), light scattering coefficient at $545 \mathrm{~nm}\left(\sigma_{s}\right.$, solid circles) and CO mixing ratio (open circles) at 30 min intervals in the biomass burning season at the surface station (FNS). The rainfall (arbitrary units) is shown by the vertical bars.

variability up to 2 orders of magnitude is observed in $\sigma_{s}$, $\sigma_{a}, \mathrm{PM} 2.5$, and $\mathrm{CO}$ with values ranging $5-1435 \mathrm{Mm}^{-1}, 1-$ $70 \mathrm{Mm}^{-1}$, 2-225 $\mu \mathrm{g} \mathrm{m}^{-3}$, and 300-3500 ppb, respectively. The highest levels in $\sigma_{s}, \sigma_{a}, \mathrm{PM} 2.5$ and CO were observed during the heavily burning-influenced periods on 21, 25-26 September and 5 October (see Fig. 2). The lower values were typically observed after the rain events (e.g., 24 September, 27 September, 28 September-2 October). Some of the rainfall events, for instance on 28 September (vertical bars, Fig. 2), resulted in dramatic reduction of aerosol and $\mathrm{CO}$ concentrations. The simultaneous decrease in concentrations of aerosols and $\mathrm{CO}$ indicates that the clean-up was due to air mass replacement followed by fire suppression, while the role of scavenging was likely low. Since most of the period (16 September-8 October) is dominated by biomass burning aerosols (except for a few rain events), the aerosol properties along with $\mathrm{CO}$ are representative of biomass burning conditions.

Figure 3 shows the correlations of $\sigma_{s}$ with PM2.5, CN, CO and also $\sigma_{a}$ with PM2.5 at the pasture site FNS during the burning period. There are two populations of points in $\sigma_{a}$ and $\sigma_{s}$. The number of points in the second population is less than $1 \%$ of total data, so correlations are dominating by the first population. The $\sigma_{s}$ and $\sigma_{a}$ of the aerosols are positively correlated with PM2.5, CN and CO. Good correlation 

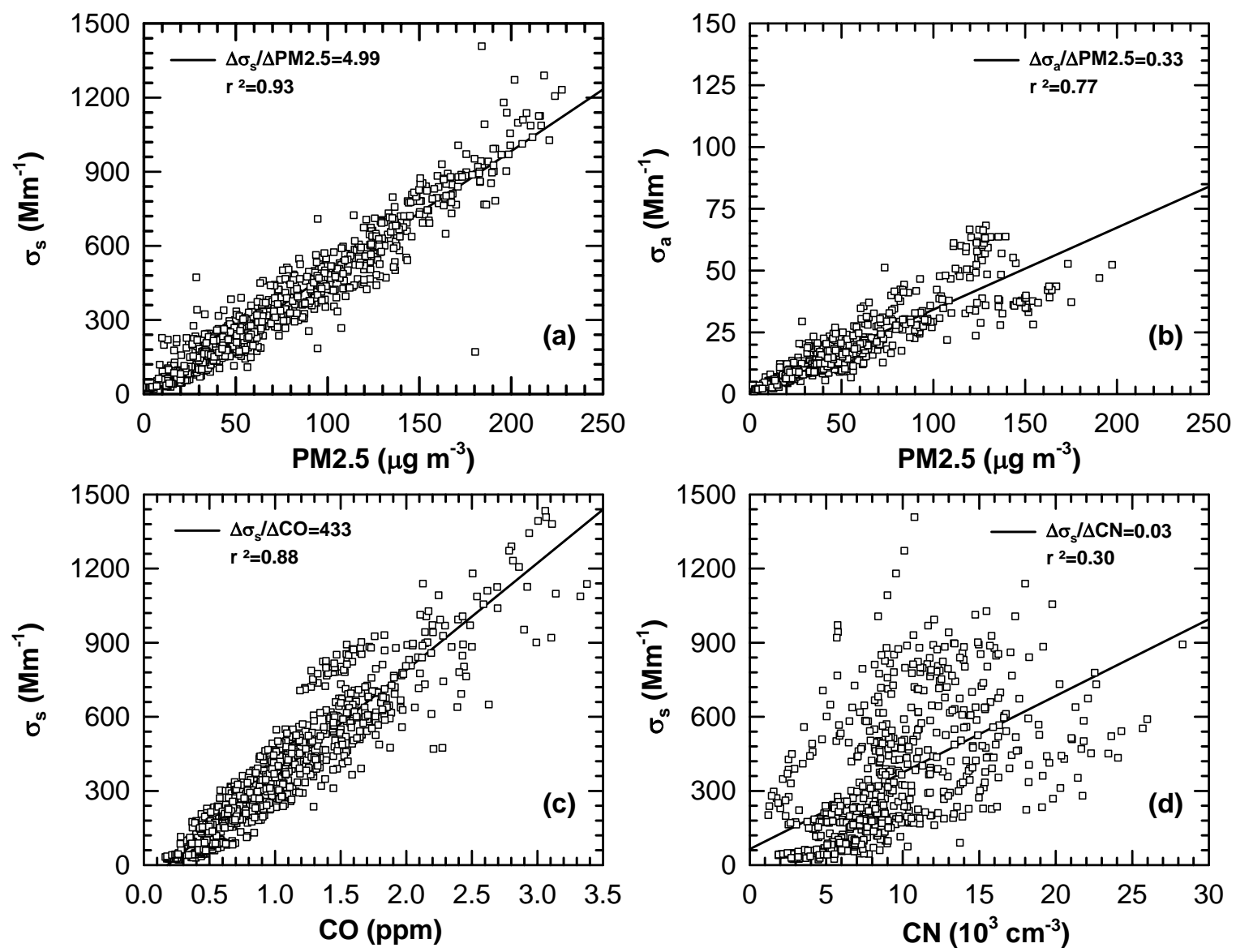

Fig. 3. Scatter plots and regression lines for 30-min averaged data of (a) light scattering coefficient $\left(\sigma_{s}\right)$ at $545 \mathrm{~nm}$ versus aerosol mass concentration (PM2.5) at the ground station (FNS) during the biomass burning season. Similarly, (b) the light absorption coefficient ( $\left.\sigma_{a}\right)$ at $545 \mathrm{~nm}$ versus PM2.5, (c) $\sigma_{s}$ versus $\mathrm{CO}$, and (d) $\sigma_{s}$ versus aerosol number concentration $(\mathrm{CN})$. The slopes are least-square-fitted lines. The corresponding correlation coefficients $\left(\mathrm{r}^{2}\right)$ of these parameters are shown on the respective plates.

is found between $\sigma_{s}$ and PM2.5 $\left(\mathrm{r}^{2}=0.93\right)$ as well as between $\sigma_{s}$ and $\mathrm{CO}\left(\mathrm{r}^{2}=0.88\right)$. The correlation between $\sigma_{a}$ and PM2.5 $\left(\mathrm{r}^{2}=0.70\right)$ is not as good as for $\sigma_{s}$ and PM2.5. Poor correlation $\left(\mathrm{r}^{2}=0.30\right)$ is observed between $\sigma_{s}$ and $\mathrm{CN}$.

The average slopes of $\sigma_{s}$ and $\sigma_{a}$ with PM2.5 $\left(\Delta \sigma_{s} / \Delta \mathrm{PM} 2.5, \quad \Delta \sigma_{a} / \Delta \mathrm{PM} 2.5\right)$ are the average mass scattering efficiency $\left(\alpha_{s}\right)$ and mass absorption efficiency $\left(\alpha_{a}\right), 5.0$ and $0.33 \mathrm{~m}^{2} \mathrm{~g}^{-1}$, respectively, during the burning period. The observed $\Delta \sigma_{s} / \Delta \mathrm{CO}$ is $0.433 \mathrm{Mm}^{-1} \mathrm{ppb}^{-1}$ (Fig. 3c). We note here that since the cut point $\left(\mathrm{D}_{p}\right)$ for the measurements of $\sigma_{s}$ and $\sigma_{a}$ is $1.5 \mu \mathrm{m}$, compared to PM2.5, our values are a lower estimate of the true $\alpha_{s}$ and $\alpha_{a}$ for these particles. The mass difference between PM1.5 and PM2.5 is less than $10 \%$ of PM2.5 during the dry season (Chand et al., 2006 ${ }^{2}$ ).

The average $\omega_{o}$ for dried aerosols $(R H=20-40 \%)$, calcu-

2 Chand, D., Schmid, O., Vestin, A., Artaxo, P., Frank, G. P., Guyon, P., Gatti, L. V., Swietlicki, E., and Andreae, M. O.: Diurnal variations in optical properties of aerosols at a pasture site over the Amazon Basin, in preparation, 2006. lated using Eq. (3), is about $0.92 \pm 0.02$. This $\omega_{o}$ is consistent with the $\omega_{o}$ calculated from the AERONET data (0.92) obtained from the nearby site Abracos hill ( $4 \mathrm{~km}$ from FNS). Also, the observed $\omega_{o}$ is close to the earlier study conducted over the Amazon basin (Dubovik et al., 2002). At higher $R H$ $\left(>60 \%\right.$ ), the $\omega_{o}$ may be higher compared to the observed $\omega_{o}$ at drier conditions. The $\omega_{o}$ and other optical parameters showed pronounced diurnal variations, which will be discussed in detail in Chand et al. $(2006)^{2}$. The hourly average values of $\omega_{o}$ at midnight (00:00 local time, LT) and midday (12:00 LT) are $0.91 \pm 0.02$ and $0.94 \pm 0.02$, respectively. The daytime aerosols are representative of a deeper boundary layer height $(\sim 1600 \mathrm{~m})$ than night time aerosols with a boundary layer height of about $200 \mathrm{~m}$. Due to different mixing and transport times in the BL during day and night, the daytime aerosols are generally more aged than the aerosols in night time (Rissler et al., 2006). Observations of higher scattering efficiency for the aerosols at higher altitudes compared to those near ground (Sect. 3.2) corroborate our observation of higher $\omega_{o}$ during day time. The size distribution and Hygroscopic Tandem Differential Mobility Analyser (HTDMA) 
observations show that the daytime aerosols have higher modal diameter compared to night time aerosols, most likely due to more aged aerosols being present in day time (Rissler et al., 2006; Chand et al., 2006 ${ }^{2}$ ). The value of $\omega_{o}$ increases with increasing size (ageing) of aerosols. Under humid conditions, the $\omega_{o}$ is likely to increase even higher, when the ageing effect is taken into account together with the higher relative humidity.

Using $\mathrm{CO}$ as a conservative tracer of biomass burning (Andreae and Merlet, 2001), the good correlation between $\sigma_{s}$ and $\mathrm{CO}$ indicates that most of the aerosols which contribute to $\sigma_{s}$ have originated from biomass combustion. Also, good correlations of $\sigma_{s}$ with PM2.5 and $\mathrm{CO}$ indicate that the scattering efficiency from the haze particles is relatively independent of the absolute pollution level during the burning period. The correlation between $\sigma_{s}$ and $\mathrm{CN}$ is not good at FNS. The poor correlation coefficient between $\sigma_{s}$ and $\mathrm{CN}$ is due to the large variability in the very small particles $(<40 \mathrm{~nm})$, which make a negligible contribution to light scattering. After excluding the aerosols below $40 \mathrm{~nm}$, there is significant correlation $\left(\mathrm{r}^{2}>0.60\right)$ between $\sigma_{s}$ and $\mathrm{CN}$ yielding a scattering efficiency of $0.016 \mathrm{Mm}^{-1}$ per particle per $\mathrm{cm}^{3}$ (Chand et al., 2006 ${ }^{2}$ ).

The average mass scattering efficiency $\left(\alpha_{s}=5.0 \mathrm{~m}^{2} \mathrm{~g}^{-1}\right)$ of the submicron dried aerosols observed in this study is consistent with the earlier observations during the LBAEUSTACH 2 campaign in September-October 1999 over the Amazon Basin (Guyon et al., 2003b). However, the mass absorption efficiency $\left(\alpha_{a}=0.33 \mathrm{~m}^{2} \mathrm{~g}^{-1}\right)$ in this study is about $10 \%$ higher than during the LBA-EUSTACH 2 campaign. The $\alpha_{s}$ and $\alpha_{a}$ of aged smoke aerosols over the tropical forest discussed by Reid et al. (2005a) are $4.1 \mathrm{~m}^{2} \mathrm{~g}^{-1}$ and $0.5 \mathrm{~m}^{2} \mathrm{~g}^{-1}$, respectively. The airborne observations of relatively young aerosols during the "Smoke Clouds Aerosols and Radiation Brazil" (SCAR-B) campaign showed a lower $\alpha_{s}\left(2.8-3.6 \mathrm{~m}^{2} \mathrm{~g}^{-1}\right)$ and higher $\alpha_{a}(0.7-1.1)$ over the Amazon Basin (Reid el., 1998a, b). The differences in observations of $\alpha_{a}$ in this study with the LBA-EUSTACH 2 and SCAR-B observations is likely due to different burning conditions, (flaming vs. smoldering), and higher particle concentrations leading to faster growth during aging processes.

\subsection{Airborne measurements}

The vertical structure and evolution of the aerosols from biomass burning can be assessed by measuring $\sigma_{s}$ along with other parameters (e.g., $\mathrm{CN}, \mathrm{CO}$ ) at the surface and aloft in the BL and FT. For example, correlations of $\sigma_{s}$ with $\mathrm{CO}$ at different altitudes can be used to get some insights on mixing/dilution of the aerosols when the air is transported from the BL to the FT. Similarly, correlations of $\sigma_{s}$ with $\mathrm{CN}$ at different altitudes can be used to get some information on evolution/ageing (coagulation, condensation, etc.) of the aerosols when the air is transported from the BL to the FT.

Inter-comparison between the observations at FNS and on the aircraft was made using day time observations during the seven fly-by flights at heights of $150-600 \mathrm{~m}$ above FNS. The ratios of the $\sigma_{s}$ and $\mathrm{CO}$ from airborne observation are higher by (10-25\%) during these fly-by flights. This could be attributed to the combined effects of higher $\mathrm{CN}$, higher modal diameter of aerosols and lower $\mathrm{CO}$ at the upper heights. Figures $4 \mathrm{a}$, c, e show scatter plots of $\sigma_{s}$ with $\mathrm{CN}$ from the airborne observations. The flight tracks of the covered regions are shown in Fig. 1. The excess ratios $\left(\Delta \sigma_{s} / \Delta \mathrm{CN}\right)$ represent the scattering efficiency of aerosols during the vertical profiles covering BL and FT. Depending on the altitude and nature of the aerosols (haze or fresh plumes), the scattering efficiency $\left(\Delta \sigma_{s} / \Delta \mathrm{CN}\right)$ varies significantly, as shown in Table 3 .

Similar to the variations at the ground site FNS, $\sigma_{s}$ is positively correlated with $\mathrm{CN}$ in the BL as well as in the FT. However, unlike at FNS, the airborne observations show a better correlation between $\sigma_{s}$ and $\mathrm{CN}$. The aerosols during airborne observations show two populations during most of the flights. The transition between the two populations is at an altitude between 1200 and $2000 \mathrm{~m}$. These modes, as shown by the slopes in Figs. 4a, b, c, e, and f, could be due to different ageing, size distributions and $R H$ in the BL and FT. The good correlation (high $\mathrm{r}^{2}$ ) in both modes indicates that most of the particles become optically active and contribute to light scattering when transported up from the surface to the BL and FT.

Figures $4 \mathrm{~b}, \mathrm{~d}$ and $\mathrm{f}$ show the correlation of $\sigma_{s}$ with $\mathrm{CO}$ from the airborne observations for flights 4, 6, 7, 8 and 24. A summary of $\Delta \sigma_{s} / \Delta \mathrm{CO}$ at $550 \mathrm{~nm}$ in the BL and FT is given in Table 3. Similar to the observations at the ground (FNS), the light scattering is positively correlated with $\mathrm{CO}$ in the BL with $\Delta \sigma_{s} / \Delta \mathrm{CO}$ in the range of $0.36-0.40 \mathrm{Mm}^{-1} \mathrm{ppb}^{-1}$. This value from the airborne observations is close to the surface observations at FNS $\left(\Delta \sigma_{s} / \Delta \mathrm{CO}=0.42 \mathrm{Mm}^{-1} \mathrm{ppb}^{-1}\right)$. A good agreement in $\Delta \sigma_{s} / \Delta \mathrm{CO}$ between the ground and airborne observations in the $\mathrm{BL}$ covering a large area suggests that the biomass burning aerosol sampled at FNS reflects sources typical for the entire region, with similar emission characteristics as over the rest of the Amazon Basin (Table 3). Comparing the variations of $\sigma_{s}$ with $\mathrm{CN}$ and $\mathrm{CO}$ in the $\mathrm{BL}$ and $\mathrm{FT}$, the magnitude of vertical change is higher in $\Delta \sigma_{s} / \Delta \mathrm{CN}$ than in $\Delta \sigma_{s} / \Delta \mathrm{CO}$ (Table 3). The increase in $\Delta \sigma_{s} / \Delta \mathrm{CN}$ with height suggests a substantial reduction in the relative abundance of small, weakly scattering particles in the FT compared to the particles in the BL. The particles light scattering efficiency $\left(\Delta \sigma_{s} / \Delta \mathrm{CN}\right)$ increases 2-10 times from the surface to the FT, most probably due to the combined effects of coagulation and condensation when the air parcel get aged. In addition, the large scale meteorology may also play important role in deciding the $\Delta \sigma_{s} / \Delta \mathrm{CN}$. Reid et al. (1998) has suggested a complicated effect of meteorology on optical properties of aerosols over the Amazon basin. 

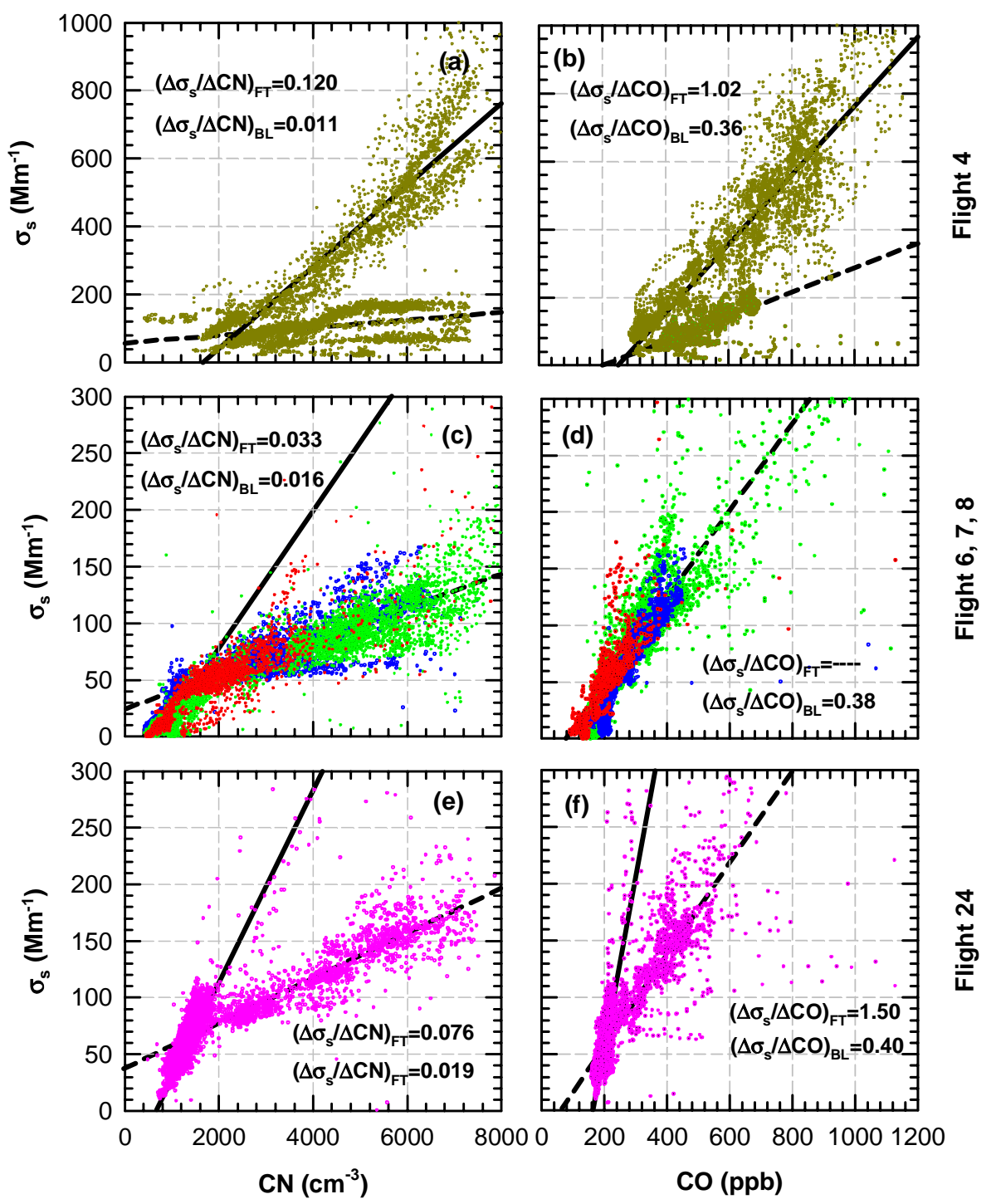

Fig. 4. Scatter plots and regression lines of the light scattering coefficient $\left(\sigma_{s}\right)$ from the airborne observations at $550 \mathrm{~nm}$ against aerosol number concentration $(\mathrm{CN})$ and $\mathrm{CO}$ for flight $4(\mathbf{a}, \mathbf{b})$; flights $6,7,8(\mathbf{c}, \mathbf{d})$; and flight $24(\mathbf{e}, \mathbf{f})$. The slopes in the BL and FT are shown by the dashed and continuous lines, respectively.

The increase in $\Delta \sigma_{s} / \Delta \mathrm{CN}$ reflects in an analysis of particle volume as a function of altitude. Figure 5 shows the total volume normalized with numbers $\left(\mathrm{V}_{n}=\right.$ ratio of total volume to the total number of aerosols) for the size range 42$346 \mathrm{~nm}\left(\mathrm{D}_{p}\right)$ of dried aerosols as a function of height during flights 4, 6, 7, 8 and 24. The $\mathrm{V}_{n}$ increases with height showing maximum level at $2000-3000 \mathrm{~m}(700-800 \mathrm{hPa})$ during all the flights. The ratio of highest $\mathrm{V}_{n}$ in FT $(\sim 2500 \mathrm{~m})$ to the lowest $\mathrm{V}_{n}$ in BL $(500 \mathrm{~m})$ varies from 1.3-1.6. Higher aerosol volume $\left(\mathrm{V}_{n}\right)$ aloft suggests that condensation of organic and possibly inorganic vapors as well as coagulation play important roles in changing the physical (size) properties of aerosol particles during ageing.
Some meteorological conditions (e.g., a strong BL inversion as observed on Flight 4 and 24), can increase the difference in $\Delta \sigma_{s} / \Delta \mathrm{CN}$ between the BL and FT. The strong inversion reduces the transport/mixing of air from the FT to the BL, and the ageing of the aerosols in the FT increases $\mathrm{V}_{n}$ and $\Delta \sigma_{s} / \Delta \mathrm{CN}$. Assuming that $\sigma_{a}$ per particle is independent of altitude during ageing, the increased $\Delta \sigma_{s} / \Delta \mathrm{CN}$ corresponds to an increase in $\omega_{o}$ up to $7 \%$ (from 0.92 to 0.98 ) for the aerosols in the FT. This assumption is corroborated by the lower $\omega_{o}$ during the night hours $(0.91)$ for less aged aerosols and the higher $\omega_{o}$ in day time (0.94) for aged aerosols. More details on the diurnal variation in optical properties of aerosols at the surface site (FNS) over the 


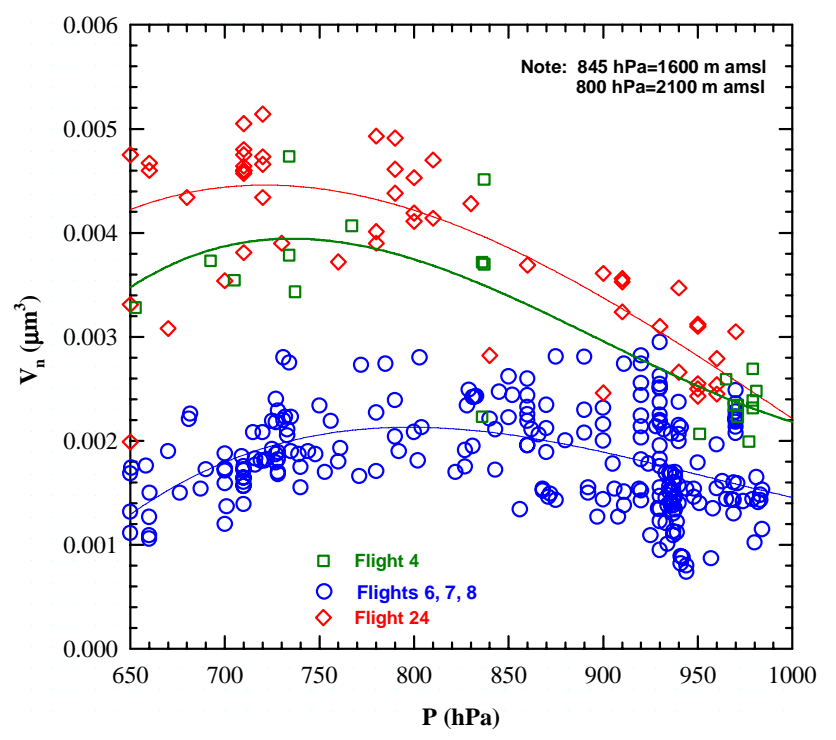

Fig. 5. Vertical variation in number-normalized total volume of aerosol $\left(\mathrm{V}_{n}\right)$ in the size range $42-346 \mathrm{~nm}$ (mobility, $\mathrm{D}_{p}$ ) during the flights $4,6,7,8$ and 24 . The curves are polynomial fits based on the least squared method.

Amazon Basin are being included in another manuscript under preparation (Chand et al., 2006 ${ }^{2}$ ).

\subsection{Vertically integrated measurements}

In order to determine whether the characteristics of aerosols measured by sunphotometry at the ground agree with in-situ measurements in the atmospheric column (BL and FT), we compared the Ångström exponents derived from independent

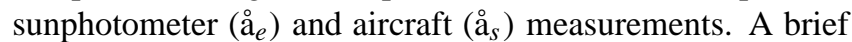
summary of $\AA_{e}$ and $\AA_{s}$ is given in Table 4 . The mean airborne $\stackrel{\circ}{s}_{s}$ from the individual flights vary in the range of 1.9 to 2.1 whereas the column integrated $\AA_{e}$ varies in the range of 1.4 to 2.0. The mean values of $\AA_{e}$ and $\AA_{s}$ are $2.0 \pm 0.4$ and $1.8 \pm 0.2$, respectively. The small difference between $\AA_{e}$ and $\AA_{s}$ suggests that (1) the absorption coefficient is not as wavelength dependent as the scattering coefficient, leading to minimal effect of light absorption on the Ångström exponent, (2) the sunphotometer results at FNS are regionally representative, and that the aerosols in the FT above the ceiling height of the aircraft did not significantly influence the value of $\AA_{e}$.

Convective activity enhances the vertical mixing and transport of aerosols in the atmosphere during the dry/burning period. An indication of the vertical extent of the aerosol column during the burning dominated period can be provided by an aerosol index called "optical scale height" $(\mathrm{OSH})$. OSH is defined as the height (in $\mathrm{m}$ ) of a homogeneous aerosol column having the same extinction coefficient $\left(\sigma_{\mathrm{ext}}=\sigma_{s}+\sigma_{a}\right)$ as the one determined at ground level, and the same AOT as the one measured by the sunphotometer. A plate of AOT $(550 \mathrm{~nm})$ vs. $\sigma_{s}$ at FNS (AOT is adjusted to the

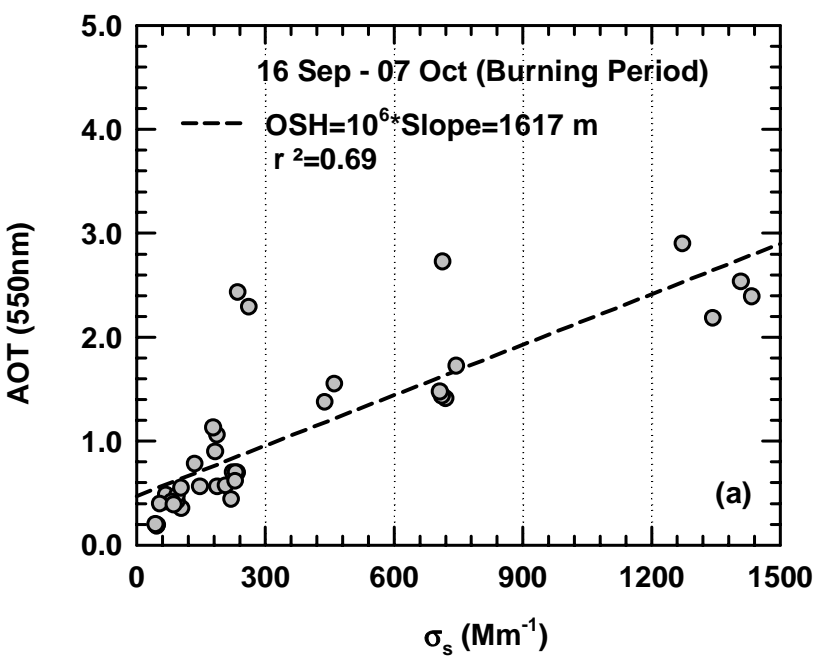

Fig. 6. Scatter plot of light scattering coefficient $\left(\sigma_{s}\right)$ with aerosol optical thickness (AOT) (both $\sigma_{s}$ and AOT at $550 \mathrm{~nm}$ ) during the biomass burning season (16 September-7 October). The AOT data are taken between 11:00 to 14:00 LT. The OSH and the correlation coefficient $\left(r^{2}\right)$ also given in the figure.

same wavelength as $\sigma_{s}$ using Eqs. 4 and 5) yields a slope corresponding to an OSH of $1617 \mathrm{~m}$ (Fig. 6). The observed OSH is very close to the average height of the day time boundary layer $(1600 \mathrm{~m})$ during the burning season obtained by radiosonde measurements (G. Fisch, personal communication; Fisch et al., 2004). The OSH is consistent with the height (1200-2000 m) where the sharp transition is observed in $\Delta \sigma_{s} / \Delta \mathrm{CN}$, as discussed in Sect. 3.2. Also, this is consistent with most of the optically active aerosols being confined to lower heights (i.e., the BL) during the burning period, as was also shown by Andreae et al. (2004; see their Fig. 2). Haze layers at higher elevations were commonly observed during the aircraft flights, but were optically much thinner than the CBL aerosol layer. This is further supported by the vertical profiles of $\mathrm{CN}$ and $\sigma_{s}$ (Fig. 7). Due to large horizontal coverage and sampling of cleaner air (background) and smoke plumes, there is large vertical variability in both $\sigma_{s}$ and $\mathrm{CN}$. However, as an average, most of the optically active aerosols are below $2000 \mathrm{~m}$ (Fig. 7). This is consistent with the OSH, as shown by Fig. 6 .

\section{Summary and conclusions}

Detailed ground and airborne measurements were taken over the Amazon Basin during the LBA-SMOCC experiment conducted during the dry season (September-October, 2002). These results have shed light on the optical and physical properties of biomass burning aerosols. The relationships between observations at the ground and in the BL and FT have been investigated. 

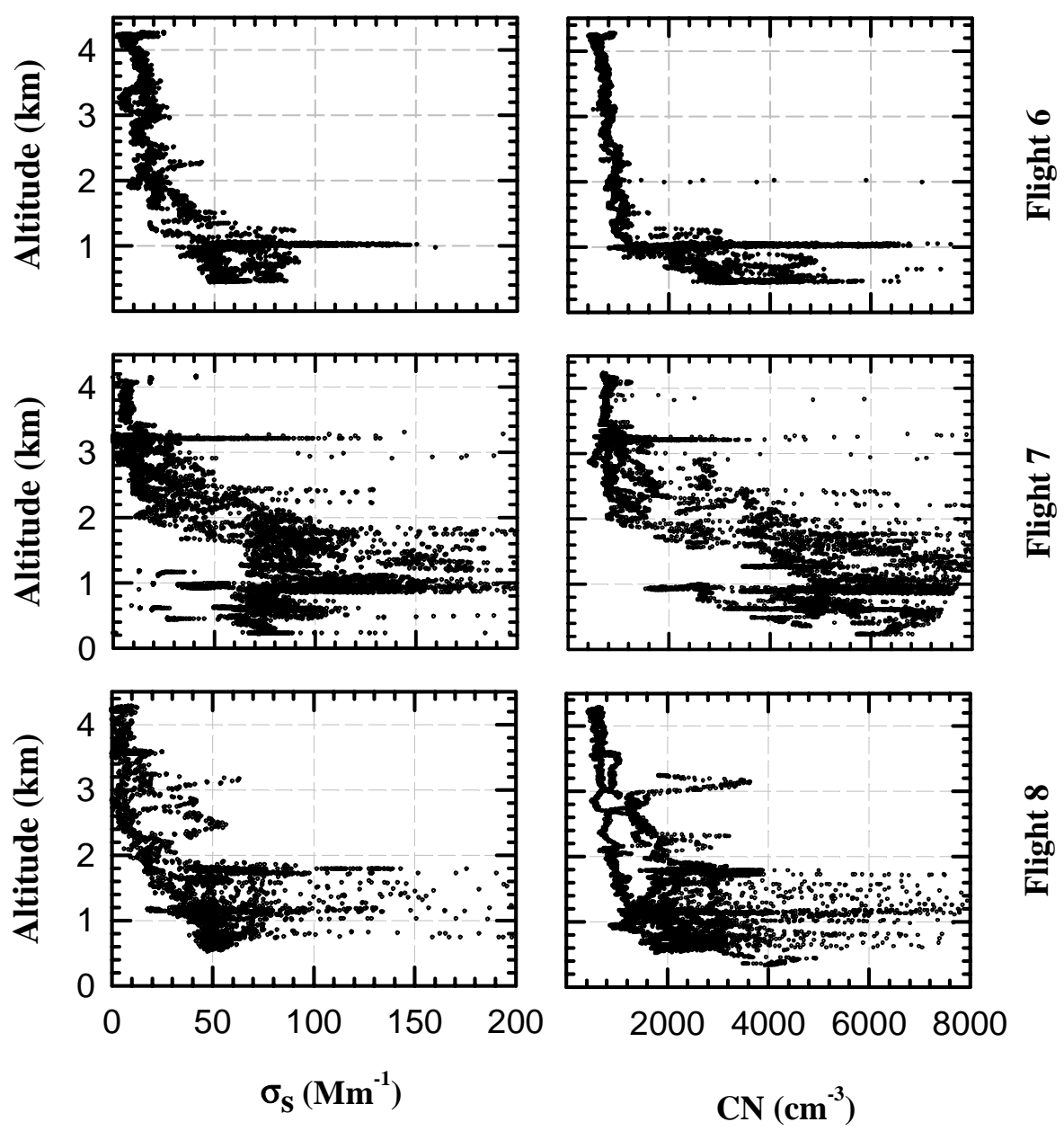

Fig. 7. Vertical variations in light scattering coefficient $\left(\sigma_{s} 550 \mathrm{~nm}\right)$ and aerosol number density $(\mathrm{CN})$ from the airborne observations (flights 6,7 and 8) during the biomass burning season (September-October) over the Amazon Basin.

In general, all the aerosol extensive properties and $\mathrm{CO}$ showed large variability during the biomass burning season. During some of the most intensive burning periods, very high mass loading (PM2.5>225 $\mu \mathrm{g} \mathrm{m}^{-3}$ ) resulted in scattering coefficients as high as $1435 \mathrm{Mm}^{-1}$ at $545 \mathrm{~nm}$. At the same time, the aerosol optical depth at $500 \mathrm{~nm}$ reached values of more than 3 and $\mathrm{CO}$ exceeded $3000 \mathrm{ppb}$. A few rain events reduced the aerosol loadings and optical effects by two orders of magnitude.

The mass scattering and absorption efficiencies, $\alpha_{s}$ and $\alpha_{a}$, relative to PM2.5 dried aerosols at about $545 \mathrm{~nm}$ at/near the ground are found to be 5.0 and $0.33 \mathrm{~m}^{2} \mathrm{~g}^{-1}$, respectively. The observed $\omega_{o}$ of dried aerosols at $545 \mathrm{~nm}$ is $0.92 \pm 0.02$. The $\Delta \sigma_{s} / \Delta \mathrm{CN}$ in the free troposphere (between 1600 to $4200 \mathrm{~m}$ a.m.s.l.) is about 1.6 to 10.9 times higher than in the BL (below $1600 \mathrm{~m}$ a.m.s.l.). Assuming the same absorption efficiency of aerosols with altitude, this increase of $\sigma_{s}$ in the FT can increase $\omega_{o}$ up to $7 \%$ from 0.92 to 0.98 .
The Ångström exponent $(2.0 \pm 0.4)$ computed from the airborne observations below $4200 \mathrm{~m}$ is close to the Ångström exponent $(1.8 \pm 0.2)$ calculated by column integrated (sunphotometer) measurements. This suggests that (1) the absorption coefficient $\sigma_{a}$ is not as wavelength dependent as the scattering coefficient $\sigma_{s}$, leading to minimal effect of light absorption on the Ångström exponent and, (2) the sunphotometer results at FNS are regionally representative, and (3) the aerosols in the FT above the ceiling height $(4200 \mathrm{~m})$ of the aircraft do not significantly influence the value of column-integrated Ångström exponent $\AA_{e}$.

The strong correlation of $\sigma_{s}$ with PM2.5 and CO indicates that (1) most of the aerosol mass has originated from biomass combustion and (2) the smoke-laden air with different $\mathrm{CO}$ and mass loading has similar source (same $\alpha_{s}$ ) and emission characteristics. The $\sigma_{s}$ does not correlate well with the aerosol number concentration $(\mathrm{CN})$ at the ground, however, it has a better correlation aloft in the BL and FT. This indicates that the ageing process plays an important role in the optical and physical properties of aerosols. 
The correlation analysis between $\sigma_{s}$ and aerosol AOT suggests that most of the aerosols are confined to the lower levels of the atmosphere $(<1617 \mathrm{~m})$ during the burning season. This is consistent with the vertical variability of $\sigma_{s}$ and $\mathrm{CN}$. Similar levels of $\Delta \sigma_{s} / \Delta \mathrm{CO}$ at surface site and airborne observations covering a large area in the BL again suggest that the burning activities over the Amazon Basin have similar sources and fuel emission characteristics. Larger variation in $\sigma_{s}$ with $\mathrm{CN}$ than with $\mathrm{CO}$ suggest that condensationcoagulation plays an important role in changing the radiative properties of aerosols. The scattering efficiency of aerosols $\left(\mathrm{V}_{n}\right)$ increases with height, having a maximum at 1700 $3000 \mathrm{~m}$.

This is the first study presenting a comprehensive data set on optical properties of aerosols at the ground, BL and FT in the dry season over the Amazon Basin. This data set, along with the data from the SCAR-B and LBA-EUSTACH2 campaigns, can be used to validate the optical parameters retrieved from satellites. The combined ground, airborne and remote sensing observations can be valuable to assess the role of biomass burning and its impact at local, regional and global scales.

Acknowledgements. We thank all members of the LBASMOCC Experiment. We are especially grateful for the support of J. von Jouanne, M. Welling, G. Nishioka, A. Ribeiro, A. L. Loureiro, T. Germano, and the pilots of the Universidad Estadual do Ceará (UECE) and Instituto Nacional do Pesquisas Especiais (INPE) Bandeirante aircraft. We thank T. W. Andreae for reviewing the text of this article. The first author, D. Chand, is grateful to F. X. Meixner, G. Helas, S. Lal (PRL, Ahmedabad), S. K. Satheesh (IISc, Bangalore), A. Hoffer, U. Dusek, and the LBA-SMOCC community for discussions and encouragements. This project was funded by the European Commission (Project SMOCC), the Max Planck Society, the FAPESP - Fundação de Amparo á Pesquisa do Estado de São Paulo, and the Conselho Nacional de Desenvolvimento Cientifico (CNPq) (Instituto do Milênio LBA).

Edited by: D. Rosenfeld

\section{References}

Andreae, M. O., Browell, E. V., Garstang, M., Gregory, G. L., Harriss, R. C., Hill, G. F., Jacob, D. J., Pereira, M. C., Sachse, G. W., Setzer, A. W., Dias, P. L. S., Talbot, R. W., Torres, A. L., and Wofsy, S. C.: Biomass-burning emissions and associated haze layers over Amazonia, J. Geophys. Res.-Atmos., 93, 1509-1527, 1988.

Andreae, M. O. and Crutzen, P. J.: Atmospheric aerosols: Biogeochemical sources and role in atmospheric chemistry, Science, 276, 1052-1058, 1997.

Andreae, M. O. and Merlet, P.: Emission of trace gases and aerosols from biomass burning, Global Biogeochem. Cycles, 15(4), 955966, 2001.

Andreae, M. O., Artaxo, P., Brandao, C., Carswell, F. E., Ciccioli, P., da Costa, A. L., Culf, A. D., Esteves, J. L., Gash,
J. H. C., Grace, J., Kabat, P., Lelieveld, J., Malhi, Y., Manzi, A. O., Meixner, F. X., Nobre, A. D., Nobre, C., Ruivo, M., Silva-Dias, M. A., Stefani, P., Valentini, R., von Jouanne, J., and Waterloo, M. J.: Biogeochemical cycling of carbon, water, energy, trace gases, and aerosols in Amazonia: The LBAEUSTACH experiments, J. Geophys. Res.-Atmos., 107(D20), 8066, doi:10.1029/2001JD000524, 2002.

Andreae, M. O., Rosenfeld, D., Artaxo, P., Costa, A. A., Frank, G. P., Longo, K. M., and Silva-Dias, M. A. F.: Smoking Rain Clouds over the Amazon, Science, 303, 1337-1342, 2004.

Anderson, T. L. and Ogren, J. A.: Determining aerosol radiative properties using the TSI 3563 integrating nephelometer, Aerosol Sci. Technol., 29, 57-69, 1998.

Ångström, A.: On the atmospheric transmission of Sun radiation and on dust in the air, Geogr. Ann., 12, 130-159, 1929.

Artaxo, P., Fernandes, E. T., Martins, J. V., Yamasoe, M. A., Hobbs, P. V., Maenhaut, W., Longo, K. M., and Castanho, A.: Large Scale Aerosol Source Apportionment in Amazonia, J. Geophys. Res., 103(D24), 31 837-31 848, 1998.

Artaxo, P.: The atmospheric component of biogeochemical cycles in the Amazon basin, in: The biogeochemistry of the Amazon basin, edited by: McClain, M. E., Victória, R., Richey, J. E., Oxford University Press, 42-52, 2001.

Artaxo, P., Martins, J. V., Yamasoe, M. A., Procópio, A. S., Pauliquevis, T. M., Andreae, M. O., Guyon, P., Gatti, L. V., and Leal, A. M. C.: Physical and chemical properties of aerosols in the wet and dry seasons in Rondônia, Amazonia, J. Geophys. Res.-Atmos., 107(D20), 8081, doi:10.1029/2001JD000666, 2002.

Arnott, W. P., Moosmüller, H., Rogers, C. F., Jin, T., and Bruch, R.: Photoacoustic spectrometer for measuring light absorption by aerosols: Instrument description, Atmos. Environ., 33, 28452852, 1999.

Arnott, W. P., Moosmüller, H., and Walker, J. W.: Nitrogen dioxide and kerosene-flame soot calibration of photoacoustic instruments for measurement of light absorption by aerosols, Rev. Sci. Instrum., 71, 4545-4552, 2000.

Arnott, W. P., Moosmüller, H., Sheridan, P. J., Ogren, J. A., Raspet, R., Slaton, W. V., Hand, J. L., Kreidenweis, S. M., and Collett Jr., J. L.: Photoacoustic and filter-based ambient aerosol light absorption measurements: Instrument comparisons and the role of relative humidity, J. Geophys. Res.-Atmos., 108(D1), 4034, doi:10.1029/2002JD002165, 2003.

Arnott, W. P., Khadeejeh, H., Moosmüller, H., Sheridan, P. J., and Ogren, J. A.: Towards aerosol light-absorption measurements with a 7-wavelength aethalometer: Evaluation with a photoacoustic instrument and 3-wavelength nephelometer, Aerosol Sci. Technol., 39, 17-29, 2005.

Bond, T. C., Anderson, T. L., and Campbell, D.: Calibration and intercomparison of filter-based measurements of visible light absorption by aerosols, Aerosol Sci. Technol., 30(6), 582-600, 1999.

Charlson, R. J., Schwartz, S. E., Hales, J. M., Cess, R. D., Coakley, J. A., Hansen, J. E., and Hoffman, D. J.: Climate forcing by anthropogenic aerosols, Science, 255, 423-430, 1992.

Crutzen, P. J. and Andreae, M. O.: Biomass burning in the tropics: Impact on atmospheric chemistry and biogeochemical cycles, Science, 250, 1669-1678, 1990.

Eck, T. F., Holben, B. N., Slutsker, I., and Setzer, A.: Measure- 
ments of irradiance attenuation and estimation of aerosol single scattering albedo for biomass burning aerosols in Amazonia, J. Geophys. Res.-Atmos., 103, 31 865-31 878, 1998.

Eck, T. F., Holben, B. N., Reid, J. S., Dubovik, O., Smirnov, A., O'Neill, N. T., Slutsker, I.,. and Kinne, S.: The wavelength dependence of the optical depth of biomass burning, urban and desert dust aerosols, J. Geophys. Res., 104, 31 333-31 350, 1999.

Eck, T. F., Holben, B. N., Reid, J. S., O’Neill, N. T., Schafer, J. S., Dubovik, O., Smirnov, A., Yamasoe, M. A., and Artaxo, P.: High aerosol optical depth biomass burning events: A comparison of optical properties for different source regions, Gepohys. Res. Lett., 30(20), 2035, doi:10.1029/2003GL017861, 2003.

Fisch, G., Tota, J., Machado, L. A. T., Silva Dias, M. A. F., Lyra, R. F. da F., Nobre, C. A., Dolman, A. J., and Gash, J. H. C.: The convective boundary layer over pasture and forest in Amazonia, Theor. Appl. Climatol., doi:10.1007/s00704-004-0043-x, 78, 47-59, 2004.

Gash, J. H. C., Nobre, C. A., Roberts, J. M., and Victoria, R. L.: Amazonian deforestation and climate, John Wiley \& Sons Ltd, Chichester, England, 1996.

Guyon, P., Boucher, O., Graham, B., Beck, J., Mayol-Bracero, O. L., Roberts, G. C., Maenhaut, W., Artaxo, P., and Andreae, M. O.: Refractive index of aerosol particles over the Amazon tropical forest during LBA-EUSTACH 1999, J. Aerosol Sci., 34(7), 883-907, 2003a.

Guyon, P., Graham, B., Roberts, G. C., Mayol-Bracero, O. L., Maenhaut, W., Artaxo, P., and Andreae, M. O.: In-canopy gradients, composition, sources, and optical properties of aerosol over the Amazon forest, J. Geophys. Res.-Atmos., 108(D18), 4591, doi:10.1029/2003JD003465, 2003b.

Guyon, P., Graham, B., Beck, J., Boucher, O., Gerasopoulos, E., Mayol-Bracero, O. L., Roberts, G. C., Artaxo, P., and Andreae, M. O.: Physical properties and concentration of aerosol particles over the Amazon tropical forest during background and biomass burning conditions, Atmos. Chem. Phys., 3, 951-967, 2003c.

Guyon, P., Graham, B., Roberts, G. C., Mayol-Bracero, O. L., Maenhaut, W., Artaxo, P., and Andreae, M. O.: Sources of optically active aerosol particles over the Amazon forest, Atmos. Environ., 38, 1039-1051, 2004.

Guyon, P., Frank, G., Welling, M., Chand, D., Artaxo, P., Rizzo, L., Nishioka, G., Kolle, O., Fritsch, H., Silva Dias, M. A. F., Gatti, L. V., Cordova, M., and Andreae, M. O.: Airborne measurements of trace gas and aerosol particle emissions from biomass burning in Amazonia, Atmos. Chem. Phys., 2989-3002, 2005.

Hobbs, P. V., Reid, J. S., Kotchenruther, R. A., Ferek, R. J., and Weiss, R.: Direct radiative forcing by smoke from biomass burning, Science, 275, 1776-1778, 1997.

Hobbs, P. V., Sinha, P., Yokelson, R. J., Christian, T. J., Blake, D. R., Gao, S., Kirchstetter, T. W., Novakov, T., and Pilewskie, P.: Evolution of gases and particles from a savanna fire in South Africa, J. Geophys. Res.-Atmos., 108(D13), 8485, doi:10.1029/2002JD002352, 2003.

Holben, B. N., Eck, T. F., Slutsker, I., Tanré, D., et al.: AERONET - A federated instrument network and data archive for aerosol characterization, Remote Sens. Environ., 66, 1-16, 1998.

Horvath, H. and Trier, A.: A study of the aerosol of Santiago de ChileFII: mass extinction coefficients, visibilities and Angstrom exponents, Atmos. Environ., 27A(3), 385-395, 1993.

Intergovernmental Panel on Climate Change (IPCC): Third Assess- ment Report, Climate Change 2001: The Scientific Basis, edited by: Houghton, J. T., Cambridge Univ. Press, New York, 2001.

Kirchstetter, T. W., Novakov, T., and Hobbs, P. V.: Evidence that the spectral dependence of light absorption by aerosols is affected by organic carbon, J. Geophys. Res.-Atmos., 109, D21 208, doi:10.1029/2004JD004999, 2004.

Kirkman, G. A., Gut, A., Ammann, C., Gatti, L. V., Cordova, A. M., Moura, M. A. L., Andreae, M. O., and Meixner, F. X.: Surface exchange of nitric oxide, nitrogen dioxide, and ozone at a cattle pasture in Rondônia, Brazil, J. Geophys. Res.-Atmos., 107(D20), 8083, doi:10.1029/2001JD000523, 2002.

Kotchenruther, R. A. and Hobbs, P. V.: Humidification factors of aerosols from biomass burning in Brazil, J. Geophys. Res.Atmos., 103, 32 081-32 089, 1998.

Le Canut, P., Andreae, M. O., Harris, G. W., Wienhold, F. G., and Zenker, T.: Airborne studies of emissions from savanna fires in southern Africa. 1. Aerosol emissions measured with a laser optical particle counter, J. Geophys. Res.-Atmos., 101(D19), 23 615$23630,1996$.

Martins, J. V., Artaxo, P., Liousse, C., Reid, J. S., Hobbs, P. V., and Kaufman, Y. J.: Effects of black carbon content, particle size and mixing on light absorption by aerosol particles from biomass burning in Brazil, J. Geophys. Res.-Atmos., 103, 32 041-32 050, 1998.

Procopio, A. S., Remer, L. A., Artaxo, P., Kaufman, Y. J., and Holben, B. N.: Modeled spectral optical properties for smoke aerosols in Amazonia, Geophys. Res. Lett., 30(24), 2265-2270, doi:10.1029/2003GL018063, 2003.

Procópio, A. S., Artaxo, P., Kaufman, Y. J., Remer, L. A., Schafer, J. S., and Holben, B. N.: Multiyear analysis of Amazonian biomass burning smoke radiative forcing of climate, Geophys. Res. Lett., 31(3), L03108-L03112, doi:10.1029/2003GL018646, 2004.

Ramanathan, V., Crutzen, P. J., Kiehl, J. T., and Rosenfeld, D.: Aerosols, climate and the hydrological cycle, Science, 294, 2119-2124, 2001.

Reid, J. S. and Hobbs, P. V.: Physical and chemical properties of individual biomass fires in Brazil, J. Geophys. Res.-Atmos., 103, 32 013-32 030, 1998.

Reid, J. S., Hobbs, P. V., Ferek, R. J., Blake, D. R., Martins, J. V., Dunlap, M. R., and Liousse, C.: Physical, chemical, and optical properties of regional hazes dominated by smoke in Brazil, J. Geophys. Res.-Atmos., 103, 32 059-32 080, 1998.

Reid, J. S., Eck, T. F., Christopher, S. A., Koppmann, R., Dubovik, O., Eleuterio, D. P., Holben, B. N., Reid, E. A., and Zhang, J.: A review of biomass burning emissions part III: intensive optical properties of biomass burning particles, Atmos. Chem. Phys., 5, 827-849, 2005a.

Reid, J. S., Koppmann, R., Eck, T. F., and Eleuterio, D. P.: A review of biomass burning emissions, part II: Intensive physical properties of biomass burning particles, Atmos. Chem. Phys., 5, 799-825, 2005b.

Rissler, J., Vestin, A., Swietlicki, E., Fisch, G., Zhou, J., Artaxo, P., and Andreae, M. O.: Size distribution and hygroscopic properties of aerosol particles from dry-season biomass burning in Amazonia, Atmos. Chem. Phys., 6, 471-491, 2006, http://www.atmos-chem-phys.net/6/471/2006/.

Rosenfeld, D.: Suppression of rain and snow by urban and industrial air pollution, Science, 287, 1793-1796, 2000.

Ross, J. L., Hobbs, P. V., and Holben, B.: Radiative characteristics 
of regional hazes dominated by smoke from biomass burning in Brazil: Closure tests and direct radiative forcing, J. Geophys. Res.-Atmos., 103, 31 925-31 941, 1998.

Satheesh, S. K. and Ramanathan, V.: Large differences in the tropical aerosol forcing at the top of the atmosphere and Earth's surface, Nature, 405, 60-63, 2000.

Schmid, O., Artaxo, P., Arnott, W. P., Chand, D., Gatti, V. L., Frank, G. P., Hoffer, A., Schnaiter, M., and Andreae, M. O.: Spectral light absorption by ambient aerosols influenced by biomass burning in the Amazon Basin - I. Comparison and field calibration of absorption measurement techniques, Atmos. Chem. Pyhs. Discuss., 5, 9355-9404, 2005.

Schnaiter, M., Schmid, O., Petzold, A., Fritzsche, L., Klein, K.F., Andreae, M. O., Helas, G., Thielmann, A., Grimmler, M., Möhler, O., Linke, C., and Schurath, U.: Measurement of wavelength-resolved light absorption by aerosols utilizing a UVVIS extinction cell, Aerosol Sci. Technol., 39, 249-260, 2005.

Smirnov, A., Holben, B. N., Eck, T. F., Dubovik, O., and Slutsker, I.: Cloud screening and quality control algorithms for the AERONET data base, Remote Sens. Environ., 73, 337-349, 2000.
Terhune, R. W. and Anderson, J. E.: Spectrophone measurements of the absorption of visible light by aerosols in the atmosphere, Optics Letters, 1, 70-72, 1977.

Trebs, I., Meixner, F. X., Slanina, J., Oties, R. P., Jongejan, P., and Andreae, M. O.: Real-time measurements of ammonia, acidic trace gases and water-soluble inorganic aerosol species at a rural site in the Amazon Basin, Atmos. Chem. Phys., 4, 967-987, 2004 , http://www.atmos-chem-phys.net/4/967/2004/.

Trebs, I., Lara, L. B. L. S., Zeri, L. M. M., Gatti, L. V., Artaxo, P., Dlugi, R., Slanina, J., Andreae, M. O., and Meixner, F. X.: Dry and wet deposition of inorganic nitrogen compounds to a tropical pasture site (Rondônia, Brazil), Atmos. Chem. Phys., 6, 447-469, 2006, http://www.atmos-chem-phys.net/6/447/2006/.

Weingartner, E., Saathoff, H., Schnaiter, M., Streit, N., Bitnar, B., and Baltensperger, U.: Absorption of light by soot particles: determination of the absorption coefficient by means of aethalometer, J. Aerosol Sci., 34, 1445-1463, 2003. 